\title{
PENGGUNAAN DEMONSTRASI PLOT UNTUK MENGUBAH METODE APLIKASI PUPUK ORGANIK PADA LAHAN PERTANIAN SAYURAN DI KOTA AMBON
}

\author{
Hindersah, R., ${ }^{1}$ Hermawan, W., ${ }^{1}$ Mutiarawati, T., ${ }^{1}$ \\ Kuswaryan, S., ${ }^{1}$ Kalay, A.M., ${ }^{2}$ Talahaturuson, A. ${ }^{2}$ dan Risamasu, R. ${ }^{2}$ \\ ${ }^{1}$ Universitas Padjadjaran Jalan Raya Bandug-Sumedang Km. 21 Jatinangor 45363 \\ ${ }^{2}$ Universitas Pattimura Jalan Ir. Putuhena Kampus Poka Ambon \\ E-mail: reginawanti@gmail.com
}

\section{ABSTRAK}

Sayuran daun adalah pangan penting dalam makanan sehari-hari masyarakat Kotamadya Ambon Maluku. Di musim hujan, sayuran menjadi penyebab inflasi. Ambon juga mengimpor sayuran non daun dari beberapa kota di Jawa dan Sulawesi. Salah satu masalah produktivitas sayuran adalan supply pupuk anorganik yang tidak kontinyu dan harganya mahal. Pemupukan organik dapat menjadi alternatif, saat ini petani sudah menggunakan pupuk organik berupa kotoran ayam dengan cara ditaburkan. Metode ini diyakini tidak efisien dan kurang efekfif. Tujuan pertama dari Program Pengabdian kepada Masyarakat ini bertujuan untuk memperoleh informasi mengenai pemahaman petani terhadap fungsi pupuk. Tujuan kedua adalah melaksanakan demonstrasi plot cara aplikasi pupuk organik yang benar di lahan pertanian sayuran daun, dalam kerangka peningkatan produktivitasnya. Kegiatan Focus Group Discussion sebelum demonstrasi plot dilakukan di area pertanian sayuran Dusun Waiheru Desa Waiheru Kecamatan Baguala Kota Ambon untuk satu musim tanam di musim kemarau. Dua perlakuan demonstrasi plot adalah aplikasi pupuk kotoran di permukaan tanah setelah tanaman tumbuh; dan pupuk kotoran dicampur dengan tanah bagian atas sebelum tanam. FGD memberikan kejelasan bahwa petani cukup mengerti peran pupuk organik namun ketiadaan pupuk organik kadang-kadang menghambat aplikasi yang tepat waktu. Sebagian besar petani juga tidak berminat membuat pupuk organik sendiri. Demplot di pertanaman sawi hijau (Brassica rapa L.), kangkung (Ipomoea aquatica L.) dan bayam (Amaranthus sp.) memperlihatkan bahwa pencampuran bahan organik dengan tanah dapat meningkatkan hasil sayuran dibandingkan dengan penaburan bahan organik di permukaan tanah.

Kata kunci: Ambon, Demonstrasi Plot, Pupuk Organik, Sayuran Daun.

\section{ABSTRACT}

Leafy vegetables are important in daily diet of Ambon residences in Mollucas. In the rainy season, leafy vegetables causes city inflation. Ambon also imports non- leafy vegetables from several cities in Java and Sulawesi. Problem to support vegetable productivity was high price and discontinued supply of inorganic fertilizers that could be substitute by organic fertilizer. Nowadys farmers are already use organic fertilizer in form of chicken manure. Application method of manure is believed inefficient since manure are sown in soil surface after planting. The first objective of the Community Service Program was to obtain information about the farmers' understanding of the function of fertilizer. The second objective was to carry out a demonstration plot concerning appropriate application methode of organic fertilizer in leafy vegetables production, within the framework of an increase the productivity. Focus Group Discussion was conducted before demonstration plots in vegetable farming area in Waiheru village, Baguala District of Ambon City for one growing season in the dry season. Two demonstration plot treatments were application of organic fertilizer on the soil surface after the plants grown; and organic fertilizer mixed with top soil before planting. Three vegetable grown in demonstration plots were caysim, amaranth and water spinach. FGD verified that farmers were understand the role of organic fertilizer, but lack of organic fertilizers in planting season caused they did not applied in at the right time. Most farmers were not interested in making their own organic fertilizer. It was showed that mixing with soil organic matter could increased vegetables yield compared to the sowing of organic matter on the soil surface.

Key words: Ambon, Demonstration Plot, Organic fertilizer, Leafy Vegetables

\section{PENDAHULUAN}

Sayuran daun diproduksi intensif oleh petani di Kota Ambon, terutama sekitar Teluk Ambon, dengan penanaman hampir sepanjang tahun namun aktivitasnya menurun saat musim hujan. Sayuran dalam perekonomian Maluku menjadi salah satu penyumbang inflasi karena pada musim hujan, produksi sayuran menurun dan harga meningkat. Sentra sayuran di Kota Ambon terpusat di Desa Waiheru (Kecamatan Teluk Ambon), Desa Wayame (Kecamatan Baguala) dan 
ekstensifikasi ke Tawiri di Kecamatan Teluk Ambon. Sayuran ditanam pula di Ambon bagian perbukitan seperti di Desa Telaga Kodok dan Desa Rumah Tiga. Fokus program PKM Unpad dilakukan di Desa Waiheru (Gambar 1) yang termasuk pioner di Ambon. Sayuran yang dibudidayakan adalah sawi hijau (Brassica dapa L.), Kangkung (Imopoea aquatica) dan bayam merah dan hijau (Amaranthus spp.). Pemilihan komoditas sayuran berumur pendek, 15-21 hari, didorong oleh cepatnya perputaran uang dan secara teknis tepat ditanam di tanah yang tidak terlalu subur dengan kadar unsur hara makro Nitrogen dan Fosfor rendah.

Masalah pertanian sayuran di Teluk Ambon adalah suplai bahan organik bersubsidi terbatas sedangkan petani belum terbiasa membuat kompos sendiri. Satu-satunya sumber bahan organik adalah pupuk kotoran ayam yang dibeli dari peternak ayam pedaging atau petelur. Kondisi ini menyebabkan praktek pemupukan sering tidak mengikuti kaidah yang benar. Jika pupuk organik diperoleh setelah tanam, maka pupuk diberikan dengan cara ditaburkan. Aplikasi ini tidak efisien untuk mencapai tujuan manfaat pupuk organik yaitu perbaikan struktur tanah, penyediaan unsur hara nitrogen, fosfor, kalium dan peningkatan perkembangan mikroba potensial di dalam tanah (Hartatik dan Widowati, 2006). Tujuan pemupukan organik adalah mengkompensasi kehilangan bahan organik tanah yang dapat dilakukan dengan cara aplikasi di dalam larikan (Edi dan Bobihoe, 2010), disebar di permukaan tanah kemudian dicampur pada saat pengolahan tanah, dan dalam lubang-lubang tanam (Hartatik dan Widowati, 2006). Aplikasi pupuk organik cara sebar masih dapat menyediakan unsur hara untuk tanaman namun $\mathrm{N}$ mudah menguap dalam bentuk amonia (Dierolf et al., 2000) sehingga aplikasi di dalam larikan atau lubang selalu disarankan (Bovis and Joe Touchton, 1998). Bahan organik di permukaan tanah dapat menjadi sumber patogen bagi tanaman (Dahlan et al., 2008).

Perkembangan pertanian dan hasil penelitian sering tidak diketahui oleh petani, perpindahan pengetahuan dan keterampilan terkendala komunikasi yang kurang efektif. Metode penyuluhan seperti Focus Group Discussion (FGD) dan demonstrasi plot adalah beberapa metode untuk mengintroduksi hasil penelitian ke dalam praktek pertanian sesungguhnya di tingkat petani. Penyuluhan adalah metode efektif untuk mengkomunikasikan pengetahuan dan keterampilan, juga untuk membangkitkan minat dan menstimulasi petani untuk mulai mempraktekan sesuatu yang baru. Focus Group Discussion (FGD) adalah metode pengkajian cepat, untuk mendapatkan data dengan metode semi terstruktur yang ditujukan pada partisipan yang sengaja dipilih untuk berdiskusi tentang tema yang ditentukan oleh fasilitator (Kumar 1987). Demonstrasi plot (Demplot) adalah salah satu metode terbaik untuk memperbaiki hasil, dan dimanfaatkan oleh para penyuluh untuk memperoleh perubahan perilaku yang diinginkan di masyarakat pedesaan. Dengan demplot akan terjadi situasi pembelajaran, serta komunikasi dan interaksi antara penyuluh dan petani. Setidaknya melalui FGD dan demplot akan ada perubahan pengetahuan, opini, aspirasi dan keterampilan; yaitu perubahan perilaku terendah setelah program intervensi menurut 'Bennett' $\mathrm{s}$ Hierarchy” (Radhakrishna, 2010).

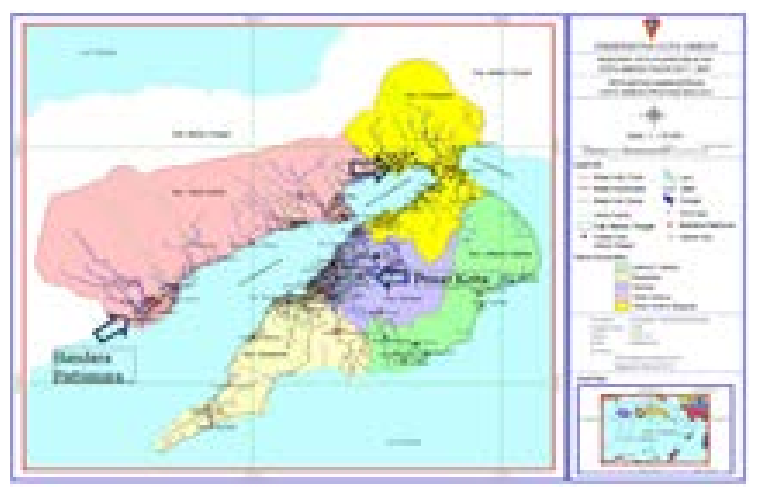

Gambar 1. Lokasi kerja di Dusun Waiheru Desa Waiheru Kota Ambon yang berada di area Teluk Ambon

Saat prrogram ini akan dilakukan, belum ada data produktivitas sayuran daun di Kota Ambon. Menurut Dinas Pertanian Kota Ambon, produktivitas tanaman sayuran di Ambon adalah 60 ikat per $24 \mathrm{~m}^{2}$. Petani menjual sayuran daun dalam bentuk ikatan yang beratnya, berdasarkan beberapa sampel, adalah sekitar $0,8 \mathrm{~kg}$ dengan diameter ikatan sekitar $7 \mathrm{~cm}$, atau setara dengan produktivitas $16 \mathrm{t} / \mathrm{ha}$. Berat satu ikat bayam dan kangkung masing-masing 0,77 g dan 0,68 g. Dengan demplot, akan diperoleh data produktivitas yang lebih valid untuk ketiga jenis tanaman sayuran daun.

Tujuan dari pengabdian kepada masyarakat di Kota Ambon ini adalah 1) meningkatkan pengetahuan petani tentang manfaat pupuk melalui diskusi kelompok terfokus; 2) membandingkan efektivitas dua metode aplikasi pupuk organik terhadap hasil panen sayuran daun dan 3) memberikan rekomendasi untuk perbaikan teknik budidaya selanjutnya. Target PKM ini adalah keterlibatan sedikitnya 5 orang petani pada demplot, 2) peningkatan produktivitas tanaman sayuran daun dan 3) data produktivitas sawi, bayam dan kangkung di Dusun Waiheru. Data yang diperoleh dari demonstrasi plot diharapkan tidak saja memberikan ruang kreatif kepada petani untuk mencoba sesuatu yang baru, tetapi juga petani dapat berpartisipasi dalam aktivitas ini sehingga termotivasi untuk melalukan aplikasi pemupukan organik yang dianjurkan. Kedua hal tersebut diharapkan dapat meningkatkan produktivitas dan penghasilan petani (Khan et al., 2009). 


\section{METODOLOGI PELAKSANAAN}

Pengabdian kepada Masyarakat dilakuan bekerja sama dengan Lembaga Pengabdian kepada Masyarakat Unpatti di Dusun Waiheru Desa Waiheru Kecamatan Baguala Kotamadya Ambon Provinsi Maluku. Penjajagan untuk kesepahaman dilakukan sejak bulan Mei 2014 dan dikuatkan dengan pertemuan Tim UnpadUnpatti dengan Dinas Pertanian Kota Maluku dan Dinas Pertanian Maluku serta sejumlah UPT di bidang pertanian pada akhir Agustus 2014. Sesuai dengean petunjuk pelaksanaan FGD (Escalada dan Heong, 2009), sebelumnya tujuan FGD dikhususkan ke arah pemupukan, dengan kekhususan topik pupuk organik. Sejumlah pertanyaan untuk melacak tingkat pengetahuan petani tentang pupuk disiapkan dan akan dijadikan baseline.

Berdasarkan karakteristik kerja petani di lokasi kerja, metode yang digunakan untuk meningkatkan pengetahuan petani adalah diskusi kelompok terfokus mengenai pupuk dan pemupukan; dan pemutaran film budidaya tanaman sayuran. Diskusi terfokus diikuti oleh 15 orang petani dan 10 orang staf dari penyuluh Pertanian Lapangan dari Dinas Pertanian Kota Ambon; dilaksanakan di Kebun Petani pada 13-14 Oktober 2014. Hari pertama FGD diisi dengan pengenalan karakteristik tanah di lapangan di siang hari, pemutaran film di malam hari dan diskusi pupuk dan pemupukan keesokan harinya.

Di awal program peserta mengisi kusioner yang antara lain berisi pertanyaan yang berkaitan dengan tanah dan pupuk. Responden petani telah berkeluarga taamatan SMP dan SMA.. Mereka telah bertani di lokasi sejak 7-10 tahun yang lalu. Lahan dikelola oleh petani beserta istrinya atau orangtuanya, juga anaknya jika sudah cukup umur. Seluruh petani berasal dari Bantaeng Sulawesi Selatan.

Penjelasan karakteristik tanah diawali dengan pengambilan sampel dengan bor tanah setiap kedalaman $20 \mathrm{~cm}$ sampai kedalaman $60 \mathrm{~cm}$. Dilanjutkan dengan penjelasan kesuburan tanah dihubungkan dengan karakteristik fisik yang telihat. Penjelasan mengenai pentingnya aplikasi bahan organik yang benar dikembangkan dari kenyataan jenis tanah di Waiheru. Informasi mengenai budidaya tanaman sayuran diberikan melalui film berjudul Teknik Budidaya dengan Rumah Screen" produk kerjasama Saung Nirwan, Universitas Padjadjaran dan Balai Penelitian Sayuran Lembang Bandung.

Demonstrasi plot dilaksanakan pada 14 Oktober 2014 pada 13 lahan petani dengan luas yang berbeda (Tabel 1).

Tabel 1. Luas areal demplot pupuk organik pada tanaman sayuran daun di Dusun Waiheru Desa Waiheru Kota Ambon

\begin{tabular}{rlcccccc}
\hline \multirow{2}{*}{ No. } & Nama Petani & \multicolumn{3}{c}{ Luas lahan $\left(\mathrm{m}^{2}\right)$} & \multicolumn{3}{c}{ Kebutuhan bibit $(\mathrm{kg})$} \\
\cline { 3 - 7 } & & Kangkung & Bayam & Sawi & Kangkung & Bayam & (Karung) \\
\hline 1 & H. Mading & 80 & 80 & 0 & 3 & 0,25 & 5 \\
2 & Rahman & 130 & 0 & 120 & 4 & 0 & 7 \\
3 & Nardis & 120 & 60 & 0 & 4 & 0,25 & 5 \\
4 & Doddin & 0 & 65 & 70 & 0 & 0,25 & 4 \\
5 & Boleng & 60 & 90 & 130 & 0 & 0,25 & 7 \\
6 & Daeng Kama & 0 & 135 & 165 & 0 & 0,50 & 8 \\
7 & Suman & 0 & 48 & 132 & 0 & 0,25 & 5 \\
8 & Darwis & 75 & 0 & 80 & 3 & 0 & 5 \\
9 & Alimuddin & 120 & 70 & 0 & 4 & 0,25 & 6 \\
10 & Sarahuddin & 80 & 90 & 0 & 3 & 0,25 & 5 \\
11 & Salawa & 60 & 48 & 0 & 2 & 0,25 & 4 \\
12 & Suhardi & 0 & 120 & 0 & 2 & 0,33 & 4 \\
13 & Tasri & 120 & 100 & 0 & 4 & 0,25 & 7 \\
14 & Hawin & 0 & 100 & 120 & 0 & 0,25 & 7 \\
15 & Ahmad & 0 & 150 & 150 & 0 & 0,50 & 8 \\
16 & H. Samrin & 170 & 120 & 0 & 5 & 0,25 & 7 \\
& Jumlah & 1015 & 1276 & 967 & 34 & 4,08 & 94 \\
\hline
\end{tabular}


Sebelumnya dilakukan pengeboran tanah untuk memperoleh gambaran karakteristik tanah. Sampel tanah dari kedalaman $20 \mathrm{~cm}$ dianalisis di Laboratorium Kesuburan Tanah Fakultas Pertanian Unpad.

Setiap lahan dibagi dua sama ukuran untuk ditanami kangkung atau bayam. Petani menanam komoditas itu di setengah bagian lahan dengan metode pemupukan organik yang biasa dilakukan. Di setengah bagian lagi ditanam komoditas yang sama dengan pemupukan organik anjuran. Pupuk organik yang digunakan adalah pupuk kotoran ayam. Petani yang terlibat pada program demplot berjumlah 12 orang (Tabel 1) pada luasan lahan berbeda sesuai dengan yang mereka miliki. Delapan orang petani melaksanakan demplot kangkung dan tujuh orang melakukan demplot bayam hijau. Benih kedua sayuran diproduksi oleh penangkar meskipun dibeli dari Toko Pertanian. Pendampingan petani selama demplot dan panen dilakukan oleh Tim Universitas Pattimura.

Metode penanaman mengikuti kebiasaan petani setempat (Gambar 2) di atas plot tanpa guludan, yaitu:

1. Membenamkan sisa panen menggunakan traktor tangan "rotary weeder".

2. Menyisihkan bongkahan bahan organik dan batu, jika ada, dari lahan

3. Meratakan permukaan tanah dengan garu

4. Menanam benih:

a. Membuat garitan dengan jarak $10 \mathrm{~cm}$ untuk lubang tanam kangkung dengan garu, menaman benih kangkung di dalam garitan dan mentupnya dengan tanah menggunakan garu perata tanah.

b. Menebarkan benih bayam dengan merata di permukaan tanah

5. Menyiram sampai basah menggunakan selang, penyiraman tanaman masih muda dilakukan menjelang siang dan sore hari pada musim kemarau.

6. Memupuk dengan pupuk anorganik pada saat tanaman umur 7-10 dengan NPK atau urea dengan dosis $200 \mathrm{~kg} / \mathrm{ha}$ menggunakan cara tabur di permukaan tanam.

Pada plot pertama, bahan organik diberikan sebelum meratakan tanah, $20 \mathrm{t} / \mathrm{ha}$ pupuk kotoran ayam disebarkan ke permukaan dan diaduk menggunakan garu dan bercampur dengan tanah pada kedalaman sekitar $10 \mathrm{~cm}$. Pada plot lainnya, pupuk kotoran ayan dengan dosis sama ditebarkan ke permukaan tanah setelah kangkung atau bayam berkecambah pada 4 hari setelah tanam. Tanaman dipanen pada 20 hari setelah tanam dengan cara dicabut dan disatukan dalam satu ikatan dengan diameter sekitar $7 \mathrm{~cm}$ untuk sawi, bayam dan kangkung. Hasil panen dihitung berdasarkan ikatan dan dikonversi ke bobot panen dan produktivitas per satuan luas berdasarkan luas plot.

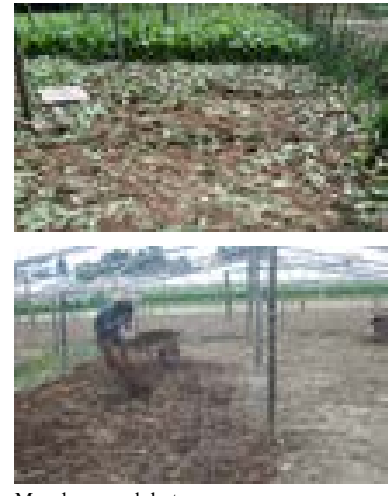

Menebar pupuk kotoran ayam

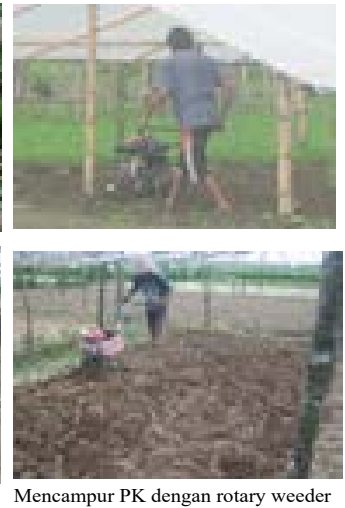

Mencampur PK dengan rotary weeder
Gambar 2. Pengolahan tanah untuk pertanaman sayuran di Dusun Waiheru dimulai dengan mencampurkan sisa panen dengan tanah menggunakan traktor tangan (atas) dan kotoran ayam ditabur setelah tanam, sedangkan untuk demplot kotoran ayam dicampurkan dengan tanah (bawah).

\section{HASIL DAN PEMBAHASAN}

\section{Status Kesuburan Tanah Dusun Waiheru}

Pengeboran dilakukan di dua lahan berbeda untuk memberikan gambaran sifat tanah kepada para petani. Tanah dari bor sedalam $60 \mathrm{~cm}$ sudah terlihat berpasir pada kedalaman 20-40 dan adanya dominasi pasir di kedalaman 40-60 cm (Gambar 3). Di bawah $60 \mathrm{~cm}$ tanah sudah berbatu yang tidak dapat ditembus oleh mata bor.

Tanah Fluvents Entisols dengan bahan induk dari endapan sungai (Soil Survey Staf, 1994). dengan karakteristik fisik cukup baik tetapi kesuburan tanah rendah. Solum tanah dalam, termasuk tanah muda dan belum berkembang, terbentuk dari bahan induk alluvium, berwarna coklat terang olive hingga Coklat kekelabuan sangat gelap bertekstur lempung, lempung berpasir dan pasir berlempung, konsistensi agak lekat. Pada kedalaman 0-20 cm, pH 5,8, C organik dan $\mathrm{N}$ total rendah sedangkan $\mathrm{P}$ dan $\mathrm{K}$ tersedia sedang.

\section{Pemahaman Petani Tentang Tanah dan Pupuk}

Enam pertanyaan tertutup mengenai tanah dan pemupukan akan memberikan gambaran tingkat pengetahuan meskipun masih secara kualitatif. Hasil kuesioner ini dirasakan penting sebagai dasar penjelasan di lapangan yang terkait karakteristik tanah dan perubahan metode pemupukan organik. Setengah responden tidak mengerti mengapa hasil tanaan tidak spanjang tahun baik. Umumnya tidak mengetahui penyebab penurunan hasil di musim hujan (72\%). Petani menganggap tanah mereka subur $(60 \%)$ karena tiga jenis tanaman sayuran daun 
selalu tumbuh dengan baik bahkan setengah dari peserta merasa mengerti tentang zat tumbuh (unsur hara) yang diperlukan tanaman. pengendalian hama diakui diketahui oleh $50 \%$, tetapi lebih dari $60 \%$ responden sebenarnya tidak tahu mengapa tanaman rusak padahal lebih dari $80 \%$ selalu mengalami kerusakan tanaman. Meskipun $52 \%$ responden pernah mendapatkan penejlasan PHT.

Petani tahu manfaat pupuk organik dan anorganik (Gambar 3) dan mengaku mengerti manfaat pupuk untuk tanah dan tanaman (83\%) serta perbedaan manfaat pupuk kotoran dan pupuk kimia untuk tanaman (83\%). Hal ini sedikit banyak dipengaruhi oleh adanya upaya dari dinas pertanian dan mungkin PPL yang menjelaskan sehingga $48 \%$ responden pernah mendapatkan penjelasan mengenai pupuk. Mereka juga meyakini bahwa tanah di Waiheru subur (64\%) meskipun mereka belum memahami bahwa sebenarnya kadar $\mathrm{C}$ dan $\mathrm{N}$ tanah rendah yang menandakan perlu upaya berkelanjutan untuk tetap menjaga kualitas tanah.

Penjelasan tentang pupuk organik kelihatannya sering dilakukan oleh Dinas Pertanian ataupun produsen benih, tetapai mereka tidak pernah membuat kompos (87\%) dan 52\% tidak ingin membuat kompos sendiri (Gambar 3). Berdasarkan FGD ada dua alasan mengapa tidak ingin membuat kompos yaitu:

1. Bahan baku dianggap sulit diperoleh karena mereka sering menganggap bahwa membuat kompos artinya menggunakan bahan dasar jerami. Di wilayah Teluk Ambon tidak ada sentra tanaman padi.

2. Pekerjaan di lapangan menyita waktu sehingga tidak bisa menyisihkan waktu untuk membuat kompos Kondisi ini sangat dipahami karena setiap keluarga petani mengelola lahannya tanpa bantuan dari person di luar keluarga.

Kuesioner sederhana ini cukup dapat menjelaskan bahwa rencana pertanian organik di Ambon belum banyak didukung oleh keinginan petani untuk memproduksi kompos sendiri. Dengan demikian pekerjaan rumah terbesar adalah bagaimana menyediakan kompos tanpa banyak partisipasi petani. Segi positifnya adalah, petani cukup mengerti peran pupuk organik, namun dari kuesioner ini tidak dapat diketahui kedalaman pengetahuan mereka tentang pupuk dan pemupukan.

\section{Produktivitas Sayuran Demplot}

Metode Demontrasi merupakan salah satu metode yang digunakan dalam kegiatan penyuluhan pertanian (Hasan, 2012). metode ini paling baik dan ampuh, sasaran penyuluhan dihadapkan pada bukti nyata berupa contoh yang dapat dilihat dan dapat diamati sendiri. Demplot membandingkan metode aplikasi pupuk organik dengan

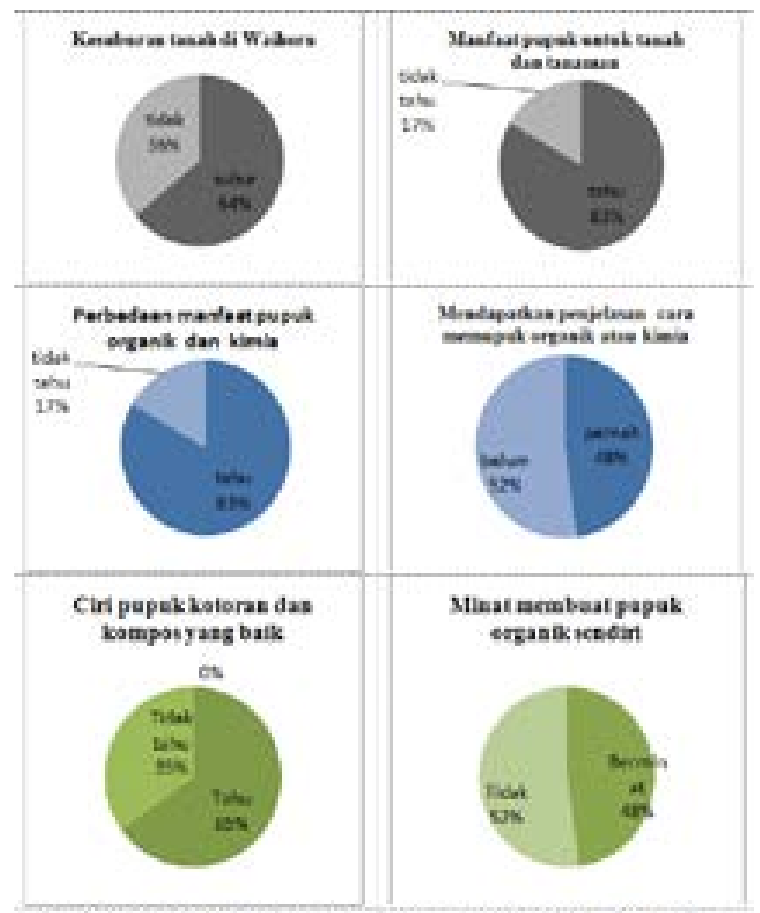

Gambar 2. Gambaran kasar pengetahuan petani sayuran mengenai pupuk organik

harapan hasil dapat ditingkatkan. Di Ambon, kuantitas hasil panen tidak dihitung dalam satuan berat tetapi dalam satuan ikatan. Perlakuan anjuran adalah mencampurkan bahan organik (dalam hal ini pupuk kotoran ayam) dengan tanah saat pengolahan tanah terakhir. Dari 14 petani yang terlibat program demplot di lahan masing-masing (Tabel 1). hanya tujuh orang yang mengaplikasikan bahan organik sesuai anjuran dengan benar dan mengukur hasil panen dengan teliti. Tujuh petani lainnya memanen tanpa koordinasi dan menyerahkan hasilnya tetapi kurang dapat dipercaya. Tanaman dipanen bertahap antara dua-tiga kali berselang 1-2 hari, dengan hasil panen dihitung per ikat. Penghitungan produktivitas (Tabel 2) berdasarkan pada bobot ikatan panen untuk sawi $0,85 \mathrm{~kg}$, bayam $0,77 \mathrm{~g}$ dan kangkung $0,68 \mathrm{~kg}$. Data tersebut adalah data rata-rata dari 10 sampel tanaman per setiap petak demplot untuk ketiga komoditas. Produktivitas per ha dihitung dengan asumsi bahwa 20\% lahan untuk utilitas.

Dari 13 plot, produksi bayam di lahan Pak Suman dan Pak Alimudin tidak berubah setelah perbaikan metode aplikasi bahan organik. Peningkatan hasil terdokumentasi di lahan lainnya.

Produktivitas sawi lebih rendah daripada sawi var Toksakan (yang banyak digunakan di Ambon) sebesar 20-25 t/ha pada umur panen 30 hari. Sawi di lokasi demplot dipanen pada hari ke 18-21. Dengan pemupukan optimum Sawi di lahan sawah 20,4 t/0,5 ha dengan tanam rapat (Krismawati dan Asmita, 2013). Produktivitas bayam pada demplot ini lebih besar daripada Bayam var Maestro untuk dataran rendah umur panen 25-30 hari sebesar $12-15$ t/ha. 
Tabel 2. Produktivitas kangkung, bayam dan sawi hijau di lahan demonstrasi plot dengan dua metode aplikasi bahan organik

\begin{tabular}{|c|c|c|c|c|c|c|c|c|}
\hline \multirow[b]{2}{*}{ No } & \multirow[b]{2}{*}{ Nama Petani } & \multirow[b]{2}{*}{ Tanaman } & \multicolumn{2}{|c|}{$\begin{array}{c}\text { Bahan Organik } \\
\text { Dibenam }\end{array}$} & \multicolumn{2}{|c|}{ Bahan Organik Ditabur } & \multicolumn{2}{|c|}{ Produktivitas (t/ha) } \\
\hline & & & $\begin{array}{l}\text { Luas } \\
\text { lahan } \\
\left(\mathrm{m}^{2}\right)\end{array}$ & $\begin{array}{c}\text { Hasil } \\
\text { panen } \\
\text { (ikat) }\end{array}$ & $\begin{array}{c}\text { Luas } \\
\text { lahan } \\
\left(\mathrm{m}^{2}\right)\end{array}$ & $\begin{array}{l}\text { Hasil panen } \\
\quad \text { (ikat) }\end{array}$ & $\begin{array}{c}\text { BO } \\
\text { dibenam }\end{array}$ & BO ditabur \\
\hline \multirow[t]{2}{*}{1} & Nardis & Kangkung & 63,25 & 140 & 64,9 & 136 & 12,0 & 11,4 \\
\hline & & Bayam & 37,8 & 80 & 37,8 & 75 & 13,0 & 12,2 \\
\hline \multirow[t]{2}{*}{2} & Suman & Bayam & 28,6 & 80 & 28,6 & 80 & 17,2 & 17,2 \\
\hline & & Sawi & 70 & 155 & 70 & 150 & 15,0 & 14,6 \\
\hline \multirow[t]{2}{*}{3} & Darwis & Kangkung & 37,2 & 130 & 37,2 & 110 & 19,0 & 16,1 \\
\hline & & Sawi & 30,15 & 90 & 45 & 125 & 20,3 & 18,9 \\
\hline \multirow[t]{2}{*}{4} & Alimuddin & Kangkung & 34,2 & 160 & 34,2 & 140 & 25,4 & 22,3 \\
\hline & & Bayam & 34,2 & 75 & 34,2 & 75 & 13,5 & 13,5 \\
\hline \multirow[t]{2}{*}{5} & Saharuddin & Kangkung & 38,76 & 105 & 38,76 & 100 & 14,7 & 14,0 \\
\hline & & Bayam & 53,11 & 131 & 36 & 90 & 15,2 & 15,4 \\
\hline \multirow[t]{2}{*}{6} & H. Samrin & Kangkung & 133,96 & 325 & 98,6 & 250 & 13,2 & 13,8 \\
\hline & & Bayam & 87,5 & 198 & 75 & 155 & 13,9 & 12,7 \\
\hline 7 & Boleng & Kangkung & 37,35 & 120 & 36 & 110 & 17,5 & 16,6 \\
\hline
\end{tabular}

Bayam di Ambon dipanen lebih awal pada umur 21 hari. Pada demplot ini, produktivitas kangkung yang ditanam 21 hari lebih tinggi daripada kangkung varieas Aura Dewi, 11,00-13,27 ton, namun lebih kecil daripada Kangkung var KK2 yang mencapai 27-28 t/ha pada umur panen 25 hari. Dengan demikian, produktivitas ketiga sayuran daun di Teluk Ambon sudah cukup baik namun masih dapat ditingkatkan dengan perbaikan teknologi budidaya.

Selama ini Dinas Pertanian Maluku hanya menghitung produktivitas dalam satuan ikatan per luasan tertentu, 60 ikat per $24 \mathrm{~m}^{2}$. Berdasarkan produksi ikatan per satu $\mathrm{m}^{2}$ yang dihitung oleh Tim Unpatti berdasarkan ubinan, diperoleh data bahwa tanpa memperhatikan metode pemupukan organik, produksi sawi dan bayam mendekati 60 ikat per $24 \mathrm{~m}^{2}$ tetapi produktivitas kangkung mencapai lebih dari 70 ikat per $\mathrm{m}^{2}$ seperti pada Tabel 3 .

Tabel 3. Jumlah rata-rata ikatan ketiga komoditas sayuran yang ditanam dengan bahan organik dibenamkan dan ditabur di permukaan tanam.

\begin{tabular}{lcccc}
\hline \multirow{2}{*}{ Komoditas } & \multicolumn{2}{c}{ Ikat/m2 } & \multicolumn{2}{c}{$\mathrm{Ikat} / 24 \mathrm{~m}^{2}$} \\
\cline { 2 - 5 } & $\begin{array}{c}\text { Bahan } \\
\text { organik } \\
\text { dibenam }\end{array}$ & $\begin{array}{c}\text { Bahan } \\
\text { organik } \\
\text { ditabur }\end{array}$ & $\begin{array}{c}\text { Bahan } \\
\text { organik } \\
\text { dibenam }\end{array}$ & $\begin{array}{c}\text { Bahan } \\
\text { organik } \\
\text { ditabur }\end{array}$ \\
\hline Kangkung & 3,12 & 2,89 & 74,9 & 69,3 \\
Bayam & 2,37 & 2,31 & 56,8 & 55,4 \\
Sawi & 2,60 & 2,46 & 62,4 & 59,0 \\
\hline
\end{tabular}

Berdasarkan pengamatan visual, Tim Unpatti sepakat dengan para petani bahwa tidak terdapat perbedaan pertumbuhan dan warna daun antara petak anjuran dan petak kebiasaan petani. Namun berdasarkan Tabel 2, pemberian pupuk organik dengan cara dicampurkan dengan tanah berpotensi memberikan hasil yang lebih baik namun tentu saja ada tambahan pekerjaan untuk mencampurkannya dengan tanah menggunakan garu. Variasi produktivitas ketiga komoditas antara plot cukup besar terutama untuk komoditas kangkung (Tabel 2) sedangkan untuk sawi dan bayam relatif konstan.. Hasil ini memberikan harapan adanya perubahan aplikasi bahan organik karena pembenaman bahan organik akan bermanfaat dalam jangka panjang. Tanah di lokasi termasuk miskin unsur hara dan berpasir. Pembenaman bahan organik terus menerus dapat meningkatkan kadar unsur hara dan mengubah komposisi ukuran butiran mineral tanah. Pemberian bahan organik dengan cara ditabur di permukaan tanah mendorong hilangnya bahan organik dengan cepat akibat dekomposisi bahan organik intensif dibawah iklim Ambon yang panas.

\section{SIMPULAN}

Produktivitas sayuran di sentra sayuran Dusun Waiheru tidak terdata dengan baik. Secara umum menurut Dinas Pertanian Maluku dari $24 \mathrm{~m}^{2}$ lahan diperoleh 60 ikat sayuran daun dengan diameter sekitar $7 \mathrm{~cm}$. GFD dan 
kuliah di lapangan memberikan kejelasan bahwa petani cukup mengerti manfaat pupuk organik. Ketergantungan petani terhadap pupuk organik eksternal yang kadangkadang tidak tersedia menyebabkan petani tidak mengaplikasikannya tepat waktu. Demonstrasi plot di Dusun Waiheru memperlihatkan bahwa mencampurkan bahan organik dengan tanah menggunakan garu berpotensi meningkatkan hasil panen. Dari 13 plot percobaan, tanpa memperhatikan komoditas, hanya dua plot yang hasilnya tidak berubah. Artinya penambahan sedikit kerja di awal tanam dapat meningkatkan hasil panen, namun pupuk organik kadang-kadang tidak diperoleh di pasaran dan petani memberikannya setelah tanam. Metode ini oleh petani dianggap dapat meningkatkan hasil kerena selama ini tidak ada pembanding. Berdasarkan demplot, data produktivitas menjadi lebih pasti karena bobot per ikat setiap jenis sayuran daun dapat ditetapkan. Demplot ini juga menjelaskan bahwa pada aera $24 \mathrm{~m}^{2}$, produksi sawi dan bayam mendekati 60 ikat per $24 \mathrm{~m}^{2}$ tetapi produktivitas kangkung mencapai lebih dari 70 ikat per $24 \mathrm{~m}^{2}$

\section{UCAPAN TERIMAKASIH}

Pengabdian kepada Masyarakat ini terselanggara atas kerjasama dengan Dinas Pertanian Pemprov Maluku dan Kotamadya Ambon, didukung oleh dana Pengabdian kepada Masyarakat dari Lembaga Penelitian dan Pengabdian kepada Masyarakat Unpad dan Lembaga Pengabdian kepada Masyarakat Unpatti. Kami berterimakasih kepada Ibu Tia Amma Kabid Tanaman Hortkultura Diperta Maluku dan staf Diperta Ambon untuk koordinasi dan bantuannya sehingga program ini berlangsung dengan baik.

\section{DAFTAR PUSTAKA}

Bovis, M. and J.Touchton, 1998. Nitrogen efficiency of urea fertilizer. Highlight of Agricultural Reseach vol 45 no. 1. Tersedia di http://www.aaes.auburn. edu/comm/pubs/ highlightsonline/spring98/ urea.html [14/11/204].

Dierolf, T., T. Fairhurst, and E. Mutert. 2000. Soil Fertility Kit: A toolkit for acid upland soil fertility management in Southeast Asia. PPI. Singapore.
Dahlan, M., Mulyati dan N. W. D. Dulur. 2008. Studi Aplikasi Pupuk Organik dan Anorganik terhadap Perubahan Beberapa Sifat Tanah Entisol Agroteksos Vol. 18 No. 1-3, Desember 2008.

Escalada, M. and K.L. Heong. 2009. Focus Group Discussion. Tersedia di http://ricehoppers. net/wp-content/uploads/2009/10/focus-groupdiscussion.pdf [27/12/2014].

Hartatik, W. dan L.R. Widowati. 2006. Pupuk Kandang. Dalam Simanungkalit, R.D.M., D. A. Suriadikarta, R. Saraswati, D. Setyorini, dan W. Hartatik (Eds). Pupuk Organik dan Pupuk Hayati. Balai Besar Litbang Sumberdaya Lahan Pertanian, Badan Penelitian dan Pengembangan Pertanian. Bogor.

Hasan,M.2012.MenerapkanMetodeDemonstrasi.Balai Besar Pelatihan Pertanian. Lembang. Tersedia di http://www.bbpp-lembang.info/index.php/en/ arsip/artikel/artikel-manajemen/605-menerap kan-metode-demonstrasi. [27/12/2014]

Khan, A., U. Pervaiz, N. M. Khan, S. Ahmad and S. Nigar. 2009. Effectiveness Of Demonstration Plots as Extension Method Adopted By AKRSP for Agricultural Technology Dissemi-nation In District Chitral. Sarhad J. Agric. 25 (2):313320

Kumar, K. 1987. Conducting focus group interviews in developing countries. A.I.D. Program Design and Evaluation Methodology Report No. 8. Washington, D.C.: U.S. Agency for International Development

Radhakrishna, R.2010. Viewing Bennett's Hierarchy from a Different Lens:Implications for Extension Program Evaluation. J. Extention. 48(6) Article Number 6TOT1, Pp. 5.

Syafri Edi, S. dan J. Bobihoe. 2010. Budidaya Tanaman Sayuran. Balai Pengkajian Teknologi Pertanian Jambi. Badan Penelitian dan Pengembangan Pertanian. Kementrian Pertanian. Jambi.

Yanti, S.E.F., E. Masru, H. Hannum. 2014. Pengaruh Berbagai Dosis dan Cara Aplikasi Pupuk Urea terhadap Produksi Tanaman Sawi (Brassica juncea L.) Pada Tanah Inceptisol Marelan. Jurnal Onaline Agroekoteknologi/Vol.2, No. 2: 770 - 780. 